Катерина Допополик

Ізмаїльський державний гуманітарний університет ORCID ID 0000-0001-5636-5701

Андрея Певсе Закарпатський угорський інститут імені Ференца Ракоці II, ORCID ID 0000-0001-8572-032X

Ірина Смирнова

Ізмаїльський державний гуманітарний університет ORCID ID 0000-0003-2085-5391 DOI 10.24139/2312-5993/2020.09/141-156

\title{
ДОСВІД ІЗМАЇЛЬСЬКОГО ДЕРЖАВНОГО ГУМАНІТАРНОГО УНІВЕРСИТЕТУ В ГАЛУЗІ ВПРОВАДЖЕННЯ ОСВІТНІХ ІННОВАЦІЙ
}

Відображений досвід Ізмаїльського державного гуманітарного університету в галузі впровадження освітніх інновацій $i$, особливо, у їх застосуванні з метою підвищення мотивації здобувачів вищої освіти сприймати знання та генерувати нові. Описане впровадження освітніх інновацій в освітній процес здобувачів вищої освіти освітньо-профресійної програми «Середня освіта: трудове навчання та технології. Інформатика», першого рівня вищої освіти на здобуття освітнього ступеня бакалавр за спеціальністю 014 Середня освіта, предметна спеціальність 014.10 Трудове навчання та технології, галузі знань 01 Освіта/Педагогіка, кваліфікація: Бакалавр освіти з трудового навчання та технологій. Учитель трудового навчання, технологій та інформатики.

Ключові слова: освітні інновачії, електронні освітні ресурси, інформачійне освітнє середовище, цифрове покоління, хмарні технології, SMART-комплекси, віртуальна реальність, учитель трудового навчання та технологій.

Постановка проблеми. На думку деяких прогностиків, трансформації, які відбудуться в найближчі декілька років в освіті України, будуть більшими, ніж зміни за останні 10 століть. Суттєвим зрушенням передують як грандіозні зміни в оновленні форм та методів упровадження інформаційних технологій (IT), так і не з'ясовані, донині, умови страшної пандемії COVID-2020. Ми порадили 6 не поспішати з оцінюванням майбутнього - те саме вважали сучасні науковці В.Биков, Р. Гуревич, А. Гуржій, М. Корець, Л. Карташова, С. Литвинова, Л. Макаренко, М. Пригодій, В. Слабко, О. Спірін, С. Яшанов та ін. на початку цього століття, коли ми почали працювати в галузі електронного навчання, і зараз немає університету без сформованого інформаційно-освітнього середовища 3 можливостями дистанційного навчання на рівні бакалаврських та магістерських освітьо-професійних програм.

Майбутнє покаже, чи є правильним це передбачення, але певно, що відбудуться зміни, і вони будуть визначальними. Питання в тому, як повинна освітня система слідувати їм, діяти паралельно, чи передбачати їх? 
Аналіз актуальних досліджень. Питаннями проблематики впровадження освітніх інновацій у заклади освіти займаються такі науковці сучасності: І. Андрощук, Т. Алексєєнко, Г. Апалат, В. Биков, С. Вернигора, А. Гуржій, С. Дзус, С. Ільченко, О.Івлієва, А. Кононенко, Л. Макаренко, Т. Метіль, В. Могилевська, М. Мусоріна, Л. Новохатько, Ю. Пивненко, М. Пригодій, Л.Сорока, В.Слабко, І.Смирнова, О.Спірін, Р. ШевченкоПерепьолкіна, М. Шишкіна, С. Яшанов, S. Kavanagh, A. Luxton-Reilly, B. Wuensche, Plimmer та ін.

Проблематикою впровадження освітніх інновацій у галузі IT-технологій у роботу Ізмаїльського державного гуманітарного університету займаються науковці: Я. Воробйов, О. Дущенко, О. Івлієва, В. Мізюк, І. Смирнова та ін.

Мета статті - відобразити досвід Ізмаїльського державного гуманітарного університету в галузі впровадження освітніх інновацій і, особливо, у їх застосуванні з метою підвищення мотивації здобувачів вищої освіти сприймати знання та генерувати нові. Надати опису впровадження освітніх інновацій в освітній процес здобувачів вищої освіти освітньопрофесійної програми «Середня освіта: трудове навчання та технології. Інформатика», першого рівня вищої освіти на здобуття освітнього ступеня бакалавр за спеціальністю 014 Середня освіта, предметна спеціальність 014.10 Трудове навчання та технології, галузі знань 01 Освіта/Педагогіка, кваліфікація: Бакалавр освіти з трудового навчання та технологій. Вчитель трудового навчання, технологій та інформатики.

Методи дослідження. Нами були використані такі теоретичні методи, як, аналіз наукових досліджень професійної педагогіки і методики професійного навчання для визначення суті, змісту і структури професійної підготовки майбутніх учителів трудового навчання та технологій, а також учителів інформатики; синтез і узагальнення - для обґрунтування основ дослідження. Також були використані такі прогностичні методи, як експертне оцінювання, узагальнення незалежних характеристик для прогностичного обґрунтування перспектив підготовки здобувачів вищої освіти за ОПП «Середня освіта: трудове навчання та технології. Інформатика».

Виклад основного матеріалу. Наразі, ми спостерігаємо конфлікт в освіті: особистостей цифрового покоління 21 століття навчають аналогові вчителі 20 століття, часто використовуючи методи 19-го! Студенти сьогодні $\epsilon$ наочними мудрецями та віртуальними виконавцями - справжніми ITгероями. Світ переживає жахливу цифрову трансформацію, і ніхто не заздритиме вчителям, якщо вони не захочуть ізолювати себе від сучасного технічного прогресу! І, якщо особистість, навіть, не належить до славної гільдії 
вчителів, але, як батьки та близькі учнів та студентів, вони мають бути добре знайомі з проблемами цифрового покоління. Протягом навчання, ми можемо досліджувати, як повільно, але впевнено розгортається розрив між системою освіти та поколінням сучасних студентів, у тому сенсі, що освіта відстає від очікувань щодо використання цифрових технологій.

Вище зазначені питання проблематики впровадження освітніх інновацій у заклади освіти займаються такі науковці сучасності: І. Андрощук, Т. Алексєєнко, Г. Апалат, В. Биков, С. Вернигора, А. Гуржій, С. Дзус, С. Ільченко, О. Івлієва, А. Кононенко, Л. Макаренко, Т. Метіль, В. Могилевська, М. Мусоріна, Л. Новохатько, Ю. Пивненко, М. Пригодій, Л. Сорока, В. Слабко, І. Смирнова, О. Спірін, Р. Шевченко-Перепьолкіна, М. Шишкіна, С. Яшанов, S. Kavanagh, A. Luxton-Reilly, B. W uensche, Plimmer та ін.

Освіта - це не хобі, але це може бути інформаційна розвага. Оскільки навчання $€$ найефективнішим, коли воно включає позитивні (віртуальні) емоції. Особливо з сучасною цифровою генерацією. Цифровому поколінню, яке також називають «генерацією із семи екранів» - на телевізорі, комп'ютері, ноутбуці, планшеті, фаблеті, смартфоні та розумних годинниках не можна і не слід навчати так, як навчали його батьків. Дане цифрове покоління не може і не буде писати на дошці крейдою. Заміна звичайної дошки білою, а крейди - маркером має лише один позитивний ефект учитель перестає вдихати крейдяний пил і заплямовує свій «фірмовий» костюм. Тобто це не спосіб мотивувати сучасних студентів накопичувати знання й розвивати навички для їх практичного застосування, адже це покоління звикло отримувати мультимедійну інформацію з Інтернету через перераховані вище пристрої, більшість із яких інтерактивні, і воно очікує побачити щось більше, ніж у звичайному закладі (Makarenko, 2020).

В умовах сьогодення, на допомогу викладачеві надані такі комплексні інтерактивні можливості впровадження освітніх інновацій, як:

- Пакети прикладних програм із різним цільовим призначенням (Microsoft Office, Lotus Smart Suite, Adobe FineReader, Adobe Page Maker, AutoCAD, Компас);

- Сервіси для створення інтерактивних завдань та групової роботи (LearningApps, Umaigra, Google J amboard, M indmeister);

- Сервіси для організації та проведення online-занять (Zoom, Google M eet);

- Відкриті освітні електронні ресурси та курси (Prometeus, EdEra, Coursera); 
- Середовища управління навчанням (Google Classroom, Moodle, Blackboard);

- Сервіси для контролю знань (Google Forms, classtime);

- Електронні бібліотеки (УкрЛіб, Libruk, Електронна бібліотека Національної бібліотеки України);

- Інформаційно-динамічні системи методичного спрямування (SM ART-комплекси, Onlinetestpad);

- Месенджери для спілкування з учнями (Viber, Telegram, WatsApp);

- Прикладні програми та сервіси для створення мультимедійного контенту (Довгополик, Бражнікова, 2019).

Тому надзвичайно важливо шляхом масового та ефективного використання інноваційних освітніх технологій та дидактичних моделей, заснованих на IT, адаптувати освітню систему до цифрового покоління, тобто виконати цифрове перетворення цієї системи. Роль викладача в закладі вищої освіти та майбутнього вчителя закладу загальної середньої освіти також повинна змінюватися. 3 передавача готових знань він повинен стати наставником, який заохочує учнів шукати потрібну їм інформацію у всесвітній павутині, аналізувати, переосмислювати та використовувати IT, і навіть синтезувати нові знання (Makarenko, 2015).

Наразі підкреслимо, що інформаційні технології - це не панацея від усіх проблем системи освіти, а лише інструмент, завдяки якому можна оновити форми та методи освітнього процесу, лекції та завдання можна зробити більш інформативними та привабливими для цифрового покоління.

Майбутній учитель-бакалавр освіти з трудового навчання та технологій, вчитель трудового навчання, технологій та інформатики має зберігати свою ключову роль у процесі інтерактивного навчання створення привабливого інформаційно-освітнього середовища закладу освіти, орієнтованого на потреби учнів закладів загальної середньої освіти.

Упровадженню даних IT-можливостей та, як результат, можливостей розроблення SMART-комплексів, передує вивчення таких спеціальних предметів: Інформаційно-комунікаційні технології за професійним спрямуванням; Методика навчання інформатики; Теоретичні основи інформатики та інформаційно-комунікаційні технології; Основи алгоритмізації та мови програмування; Комп'ютерні мережі та Інтернет; Архітектура та базове програмне забезпечення комп'ютера; Комп'ютерна графіка; Комп'ютерне моделювання; Бази даних та інформаційні системи.

Слід підкреслити, що авторитет викладача, його імідж та ефект від його роботи все більше залежатимуть не тільки від того, наскільки добре він 
опановує предмет своєї дисципліни, використовує сучасну інформацію та спілкування, технології збору, обробки й викладання відповідного навчального матеріалу, а його самоосвітні та педагогічні здібності й харизма, що формуються в період 1-2 курсів навчання на педагогічній спеціальності, завдяки реалізації професійно-педагогічного циклу дисциплін в освітньопрофесійній програмі: Педагогіка; Психологія; Методика трудового навчання, технологій і креслення; Методика навчання інформатики; Інклюзивна освіта.

У сучасній педагогіці ми маємо справу з «Цифровим поколінням» або як його називають Z, NET - це молоді люди, народжені після 1999 року. Так, поколінням NET (у мережі) або (завжди на зв'язку) вважається молодь, яка народилася під час великого Інтернет-буму.

Цифрове покоління - перше в історії, яке не уявляє повсякденного життя без IT. Вони виросли з комп'ютерною мишкою в руці, легко засвоюють та використовують нові цифрові технології. В освітній діяльності ми маємо їм запропонувати такі технології, які би сприяли їх «цифровому життю», які би реалізовували їх потреби. На рис. 1 унаочнено систематизовані науковцями сучасності потреби цифрового покоління (О. Буров та ін., 2020).

Перед системою вищої освіти стоїть головний виклик - забезпечити належне навчання для «цифрових» здобувачів, чий спосіб мислення та стиль навчання кардинально відрізняються від попереднього, «паперового» покоління здобувачів, а особливо - від викладачів, частина $з$ яких народилася і закінчила свою формальну освіту до того, як комп'ютери набули поширення в офісах та будинках були народжені до масового поширення комп'ютерів.

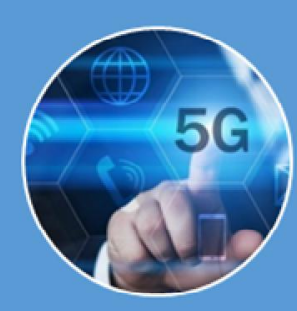

Швидке широкосмугове з'єднання 3 Internet 24/7 безкоштовно або 3 мінімальною оплатою

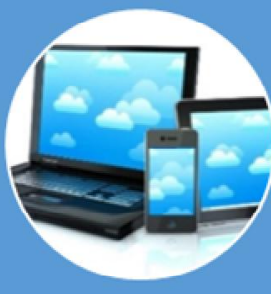

Пристрій: багатоядерний потужний процессор, якісна аудіо та відеокарта, великий об'єм оперативної пам'яті

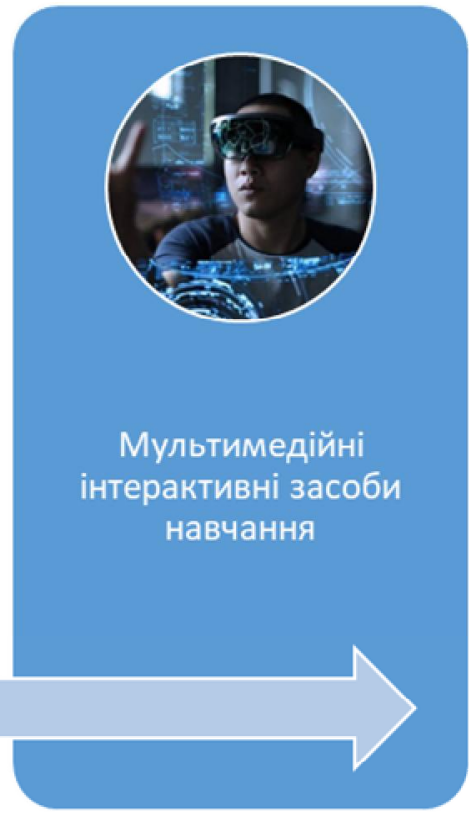

Рис. 1. Потреби цифрового покоління 
Розпочате нами експериментальне дослідження «Підготовка майбутніх учителів трудового навчання та технологій до використання SMART-комплексів в освітній діяльності» $\epsilon$ передумовою для адаптації студентів цифрового покоління до системи оновленої вищої освіти держави. Запропонована нами адаптація $\epsilon$ складною проблемою, у вирішенні якої повинні брати участь усі залучені: адміністрація, викладачі інформатики, самі здобувачі вищої освіти-майбутні викладачі технології, звичайно, необхідно залучати найкращі людські ресурси.

Ми вважаємо за потрібне запропонувати такі педагогічні умови реалізації нашого експериментального дослідження:

ӱ перехід від паперових підручників до ноутбуків та планшетів;

$\ddot{y}$ використання хмарних технологій, які значно полегшать доступ до навчальної інформації, доповнюючи мультимедійні навчальні матеріали, що зберігаються в пам'яті гаджетів, планшетів та комп'ютерів;

ӱ запровадження технологій віртуальної та доповненої реальності;

Ӱ дидактичне використання SM ART-комплексів.

Перехід від паперових підручників до ноутбуків та планшетів

Швидкі зміни з точки зору очікувань студентів щодо «ефективності» навчання та викладання, а також постійний вплив нових технологій, представляють значні фактори для більшої інноваційності у вищій освіті. На нашу думку, викладачі повинні наполегливо дізнатися більше про технологічні процеси навчання, щоб упровадити інновації у своїй освітній діяльності. Викладання дає чудову можливість освіти впродовж життя і ми маємо щастя бути частиною спільноти здобувачів, що навчаються в нашому університеті, який відкритий для інновацій та дистанційного навчання за допомогою регулярних сесій обміну знаннями.

Метою освітньої діяльності викладача $€$ забезпечення кожного студента приємним навчальним досвідом за допомогою залучення, самовідкриття за допомогою Інтернет-інструментів, індивідуальних роздумів, разом із участю в аудиторії та поза нею. Вважаємо, що використання мультимедійних засобів навчання залучає як здобувачів, так і викладачів до навчання й постійного вдосконалення в області інновацій за допомогою освітніх технологій із метою підвищення якості освіти (Смирнова, 2018).

Ретельне вивчення попиту та порівняльний аналіз пропонованих варіантів в освітній діяльності ІДГУ засвідчили необхідність використання інтерактивних панелей. Дані варіанти були оцінені як оптимальні з точки зору характеристик та цінового спрямування. Обраний варіант - інтерактивна панель - є оптимальною, оскільки: має високу роздільну здатність; дозволяє 
працювати вчителю та учню одночасно, оскільки панель розпізнає 15 одночасних точок доторку та не реагує на випадкові доторки; дозволяє підключати різноманітні пристрої, у тому числі ноутбук та смартфон; має власну операційну систему з високим рівнем захисту; дозволяє використовувати вбудовані освітні додатки, які не потребують додаткової оплати; має інтегрований кабінет учителя для більш зручної роботи та індивідуальних налаштувань; має вбудовану операційну систему, може бути включена до мережі закладу освіти. Чому освітяни наголошують на використанні інтерактивних панелей? Відповідь дуже проста. Майже всі здобувачі наразі мають сенсорні смартфони. 3 сенсорним екраном знаходяться фаблети, планшети, новіші ноутбуки та все-в-одному комп'ютери. Для студентів технологія використання сенсорного екрану - це щось цілком природне. А інтерактивна панель перетворює звичайну лекцію чи урок у цікаву гру, що підвищує їх пізнавальну активність та надає можливість студентам зосередитись.

Цікавою й дуже корисною функцією панелей є створення відеофайлу, що дозволить записати для спільного використання та повторного відтворення як відповідної презентації, так і послідовності додаткових позначень, написів та малюнків, зроблених на окремих слайдах викладачем, у т.ч. його пояснення та коментарі. Деякі виробники пропонують своїм інтерактивним системам презентацій різні корисні аксесуари, такі як камери для документів, кольорові електронні маркери, планшети, клікери тощо.

Використання хмарних технологій та систем управління навчанням

Ураховуючи, що здобувачі вищої освіти мають вже деяку інформаційну підготовленість, то впровадження основ дистанційного навчання в освітню діяльність не $є$ суттєвою проблемою. Особливо позитивно це відчувається під час підготовки фахівців - майбутніх викладачів технологій, а саме теоретичних і методичних основ їх професійної підготовки (Androshchuk, 2020).

Викладачі-науковці кафедри математики, інформатики та інформаційної діяльності ІДГУ - Я. Воробйов, О. Дущенко, О. Івлієва, В. Мізюк, І. Смирнова та ін., дбають про системну освітню підготовку майбутніх учителів технологій до розроблення й використання електронних освітніх ресурсів, створення та впровадження SMARTкомплексів (Ivliieva, 2019; Мізюк, 2019, Смирнова, 2018). Для реалізації дистанційного навчання в освітній діяльності здобувачам Ізмаїльського державного гуманітарного університету надана можливість організації навчання засобами Moodle. Особливо це стало актуальним під час 
введення карантину. Викладачі мають змогу розміщувати матеріали, надавати консультаційні та дорадчі поради, контролювати виконання й оцінювати знання здобувачів вищої освіти.

Під час вивчення дисципліни «Інформаційно-комунікаційні технології за професійним спрямуванням» майбутні вчителі трудового навчання, технологій та інформатики вчаться використовувати сучасні послуги мережі Інтернет, офісні онлайн-програми та системи управління навчанням.

Важливим у даному контексті $€$ вміння налагодити зворотній зв'язок зі здобувачами освіти. Нами запропоновано опанувати найбільш поширені месенджери, серед яких Viber, Telegram та WatsApp. Подамо на рис. 2 приклад виконаного звіту про використання месенджера Viber, реалізований засобами на платформи Moodle за дисципліною «Інформаційно-комунікаційні технології за професійним спрямуванням» для 2 курсу освітнього ступеню бакалавр за освітньо-професійною програмою «Середня освіта: трудове навчання та технології. Інформатика».

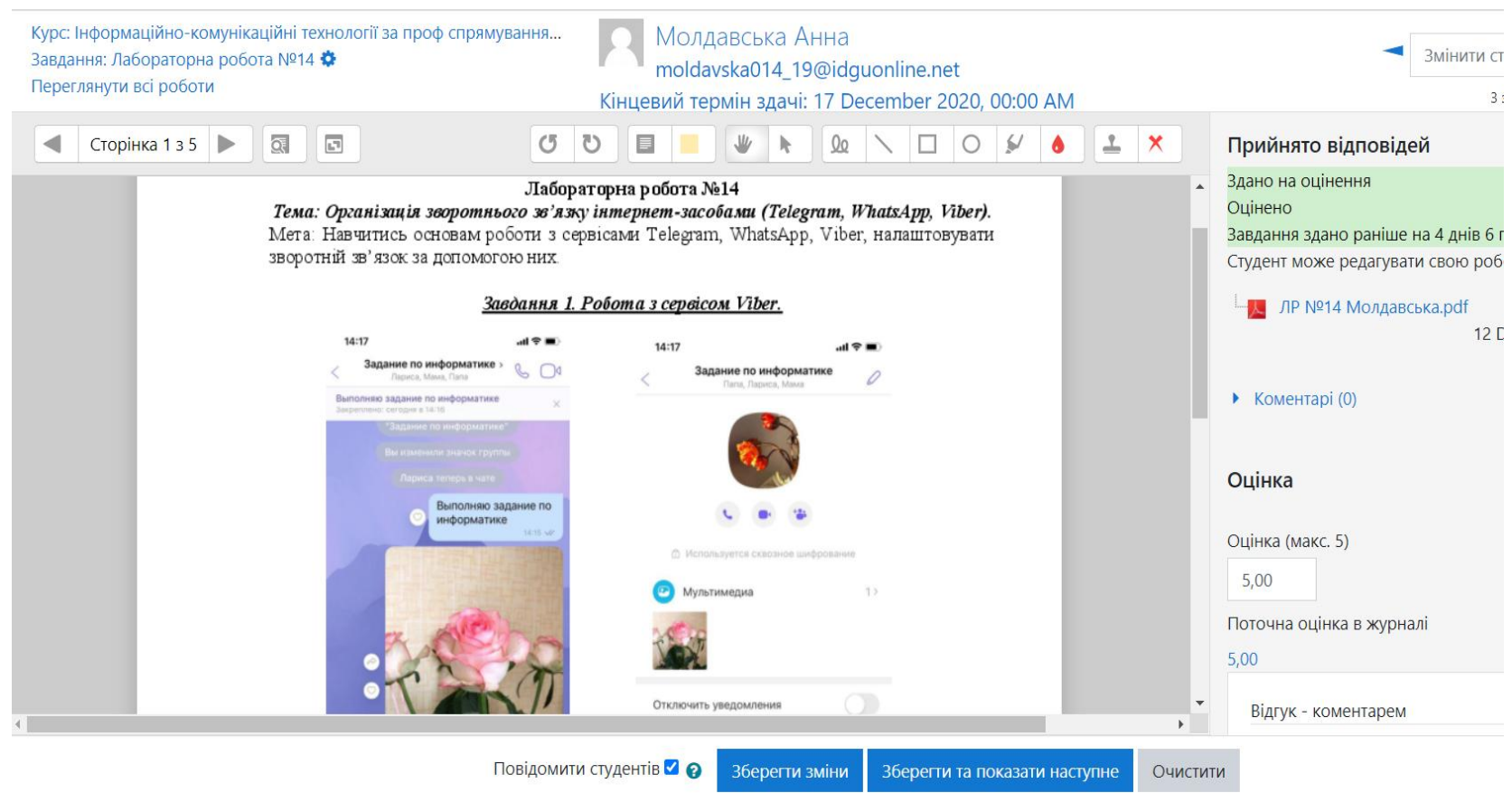

Рис. 2. Приклад виконаного звіту за лабораторно роботою на платформі Moodle (Викладач Довгополик К.)

Викладачі ІДГУ вбачають використання автоматизованої системи організації контролю знань, що включена до платформи Moodle, і надає можливість додавання різних типів запитань: багатоваріантних, відкритих, на відповідність, есе, питання правильно/неправильно, на визначення пропущених слів, перетягування об'єктів на картинку, розрахункові тощо, що створює широкий простір для проведення якісного контролю знань. Під час терміну навчання проведені модульні контрольні роботи засобами автоматичного тестування. Графічне зображення результатів тестування 
реалізовано в таблиці досягнень здобувачів 2 курсу освітнього ступеню бакалавр за освітньо-професійною програмою «Середня освіта: трудове навчання та технології. Інформатика» (рис. 3).

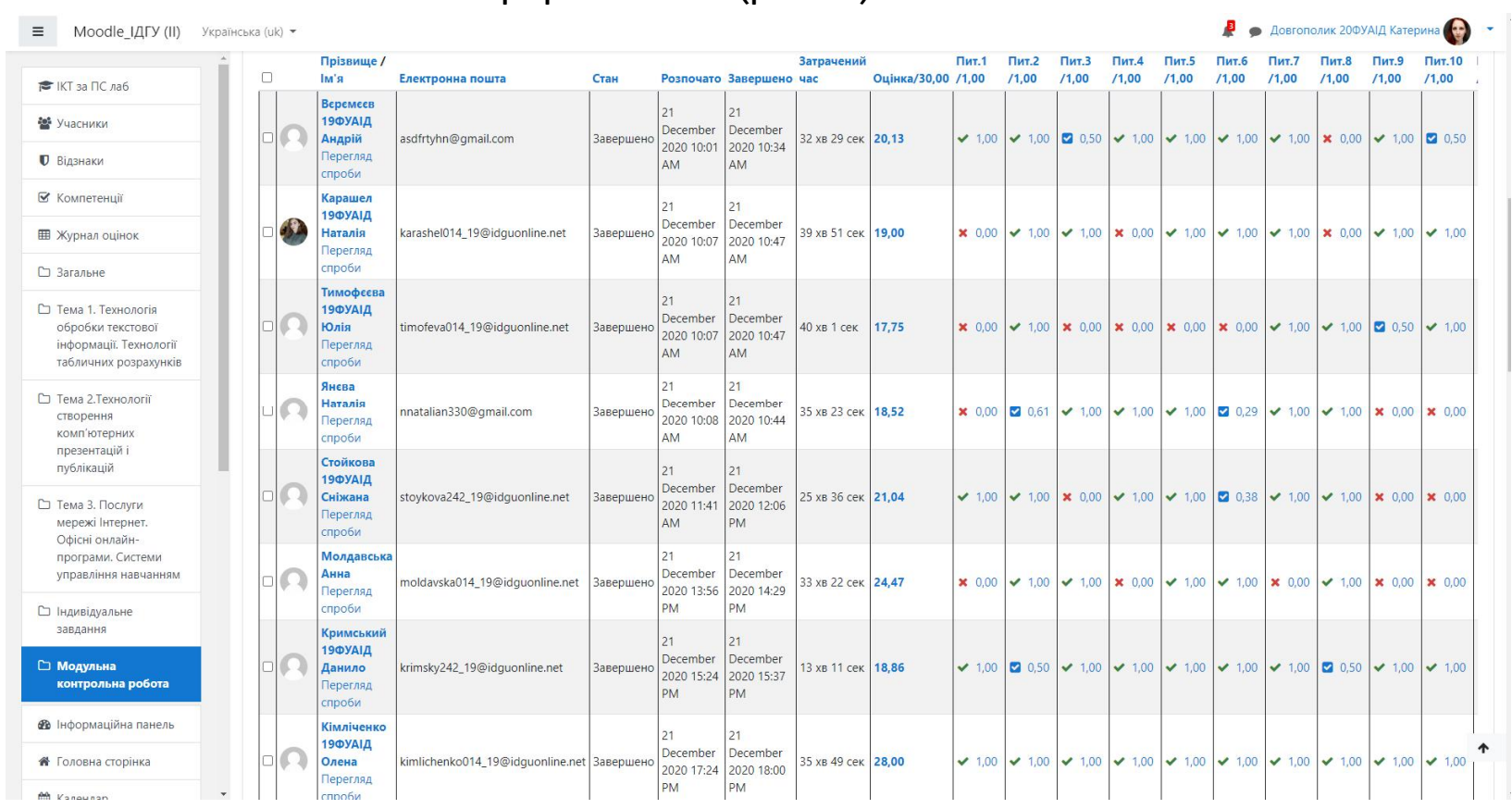

Рис. 3. Таблиця досягнень здобувачів 2 курсу освітнього ступеню бакалавр за освітньо-професійною програмою «Середня освіта: трудове навчання та технології. Інформатика»

Подаючи для прикладу графічне зображення, реалізоване за результатами тестування, зауважимо, що в Moodle автоматично формуються діаграми, на яких відслідковується статистика результатів тесту (рис. 4).
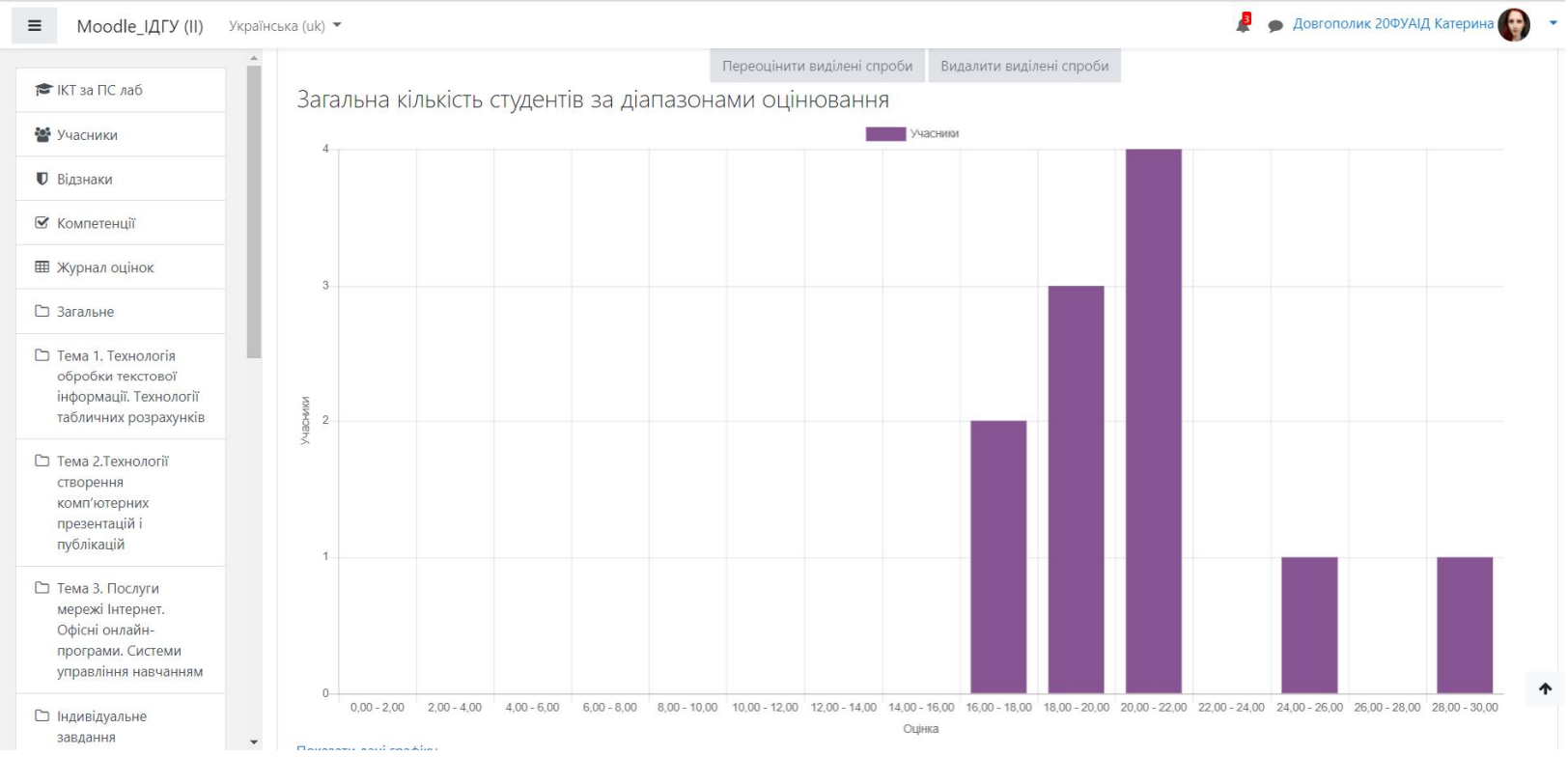

Рис. 4. Статистичні дані результатів модульної контрольної роботи 3 дисципліни «Інформаційно-комунікаційні технології за професійним спрямуванням» 
Викладачі кафедри математики, інформатики та інформаційної діяльності майстерно використовували Zoom Meetings та Google Meet для проведення лекційних, практичних, лабораторних, індивідуальних та інших видів занять на термін дії карантину, також реалізовано екзамени та інші форми контролю, за необхідності, і в усній формі, і з використанням вищезазначених сервісів.

Перевагами використання сервісів Zoom Meetings та Google Meet $\epsilon$ можливість комунікації зі студентами, демонстрації екрану для великої кількості учасників, планування свого часу через планувальник конференцій, викладач має можливість керувати учасниками, тобто не допустити до занять сторонніх осіб, вимкнути звук, зупинити відео, налаштувати чат таким чином, щоб учасники не мали ні бажань, ні можливості відволікатися на інші теми. Дуже корисною функцією $\epsilon$ перспектива віддалено керувати комп'ютером здобувача, у нашій практиці це було корисним за термін виконання здобувачами лабораторних робіт, за наявності труднощів під час виконання завдання, та під час пояснення допущених помилок у роботі здобувача.

Запровадження технологій віртуальної та доповненої реальності

На базі Ізмаїльського державного університету працює Центр інноваційних технологій, у якому здобувачі вищої освіти мають змогу набувати навичок роботи з новітніми розробками в галузі IT, а саме віртуальною реальністю, 3D-принтерами, сучасним мережевим обладнанням, комплектами Arduino для розробки електронних пристроїв та ін.

На нашу думку, важливим $є$ набуття здобувачами навичок роботи 3 віртуальною реальністю та опанування основами розробки та моделювання VR-контенту, адже сучасне цифрове покоління, це покоління, яке повинне побачити та осягнути об'єкт вивчення. Віртуальна реальність - це нереальний світ, створений за допомогою комп'ютерної обчислювальної системи і якісного аудіо- та відео обладнання. Це середовище, яке фізично не існує, його іноді називають «нефізичною реальністю». Дизайн зображень найчастіше виконується за допомогою стереоскопічних окулярів, високої вартості. Додаткова інформація про почуття людини також надається через звук, який може бути частиною моделювання. Зазвичай користувачі можуть контролювати поведінку віртуального середовища за допомогою комп'ютера, клавіатури або спеціально розробленими пристроями, такими як стилуси, контроллери та ін. Комплектація наборів може відрізнятися в залежності від фірми виробника та характеристик самого пристрою. 
Очевидно, що використання віртуальної реальності може зробити традиційні лекції чи вправи набагато інформативнішими та привабливішими для здобувачів цифрового покоління. Неважко уявити «віртуальну прогулянку» по розкопках стародавнього міста, у всесвітньо відомій картинній галереї чи в заповіднику з екзотичними тваринами, де реальне та нереальне переплітаються з метою досягнення максимального виховного ефекту. Використання віртуальної реальності для створення тренажерів у таких випадках дозволяє проводити більше тренувань за коротший проміжок часу, а це дозволяє набути необхідних компетентностей без ризику травмування, пошкодження майна, а також, що $€$ нагальною потребою, уникнення забруднення навколишнього середовища.

Звичайно, ця технологія має і свої недоліки. Неприємним ефектом використання системи віртуальної реальності $€$ поява деяких негативних наслідків для здоров'я людини. Якщо людина тривалий час працює з VR, в неї з'являються симптоми, що нагадують «морську хворобу». Причиною цього $\epsilon$ те, що тіло «говорить» мозку, що воно не рухається, але очі у віртуальній реальності бачать, що тіло рухається, тому виникає дисонанс у мозку, що призводить до такої побічної реакції. Але якщо використання технологій не є надмірним, а використання буде суворо регламентованим правилами експлуатації та технікою безпеки, з можливістю надавання організму часу для адаптації, побічні ефекти можна зменшити або повністю уникнути (Kavanagh, 2017).

На нашу думку, дані технології доцільно використовувати й під час навчання здобувачів за освітньо-професійною програмою «Середня освіта: трудове навчання та технології. Інформатика», оскільки обов'язковим $€$ використання верстатів, проте сучасна система освіти не в змозі забезпечити повністю всі потреби та швидкі зміни в оснащенні виробництва. Тому ми вважаємо за доцільне використання тренажерів із використанням VR для тренувань роботи на верстатах, станках та іншому сучасному обладнанні (рис. 5). А також використання VR під час вивчення дисциплін, спрямованих на здобуття компетентностей у галузі моделювання та проєктування.

\section{Дидактичне використання SM ART-КОМПЛЕКСIB}

Викладачі кафедри математики, інформатики та інформаційної діяльності Я. Воробйов, О. Дущенко, К. Довгополик, О. Івлієва, В. Мізюк, І. Смирнова та ін. співпрацюють із ученими Інституту професійно-технічної освіти Національної академії педагогічних наук України щодо опрацювання дидактичного використання SM ART-комплексів. Відомі науковці В. Биков, 
А. Гуржій, А. Кононенко, П. Лузан, О. Радкевич та ін. проводять лекції та семінари для викладачів і здобувачів вищої освіти, щодо розробки й упровадження інновацій у галузі IT, а саме організації освітнього середовища в закладах освіти та впровадження SM ART-комплексів.

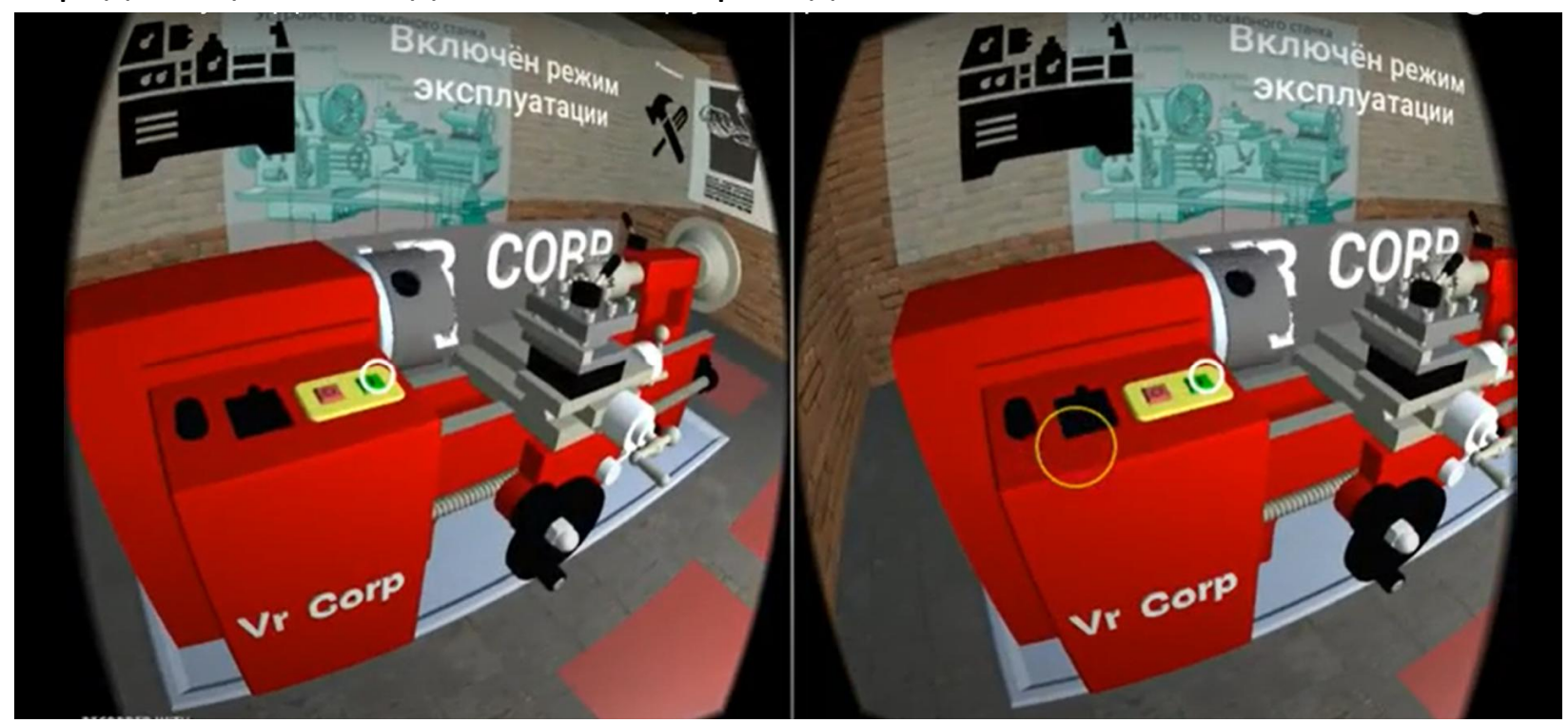

Рис. 5. Навчальний симулятор по роботі зі складним технічним обладнанням у віртуальній реальності на прикладі верстата з ЧПУ (Емельянов, 2017).

Учені (Биков та Гуржій, 2019; Кононенко, 2020; Пригодій та Криворот, 2020) визначають SM ART-комплекс як комплексну інформаційну динамічну систему освітньо-методичного спрямування, що відповідає певним критеріям: specific, measurable, attainable, relevant, time-bound та має статичну, динамічну й середовищну складові, надає цілісну інформацію про навчальний предмет із можливістю online-доступу до навчального інформаційно-освітнього середовища, а також забезпечує автоматизовану оцінку освітньої діяльності здобувачів.

Погоджуємося 3 думкою науковців, що SMART-комплекси передбачають використання великої кількості джерел, різноманіття медіа, можливість швидко і просто підлаштовуватись під рівень і потреби слухача, індивідуальний підхід до кожного здобувача та розробки курсу, без втрати активного взаємовигідного обміну власним досвідом та ідеями. Зручною для педагога $€$ можливість економії часу, який витрачається, адже наявна можливість редагування вже наявного матеріалу, замість створення його $з$ нуля. Це дає вчителю автоматизувати та оптимізувати власну роботу. А для здобувачів освіти це новий простір для пізнання, що підвищить його інтерес до предмету вивчення та здобуття інформатичних компетентностей (Макаренко, 2019; Яшанов, 2019). 
На нашу думку, використання SM ART-комплексів надає певні переваги, серед яких оптимізація змістовного поля компетентностей, яких набуває здобувач у процесі навчання; відбір найбільш ефективних методів, форм роботи та технологій педагогічного впливу для своєї професійної діяльності, які будуть найбільш актуальними для сучасного покоління; застосовування засобів та методів, що поглиблять диференціацію та індивідуалізацію навчання завдяки можливості обирати зміст навчального матеріалу, темп і режим навчання; забезпечення покрокової реалізації індивідуальної освітньої траєкторії; формування в учнів уміння самостійного здійснення навчальної діяльності з пошуку інформації, формування культури когнітивної діяльності, розвитку інтересу до пізнання, стимулювання мотивації до навчальної діяльності (Довгополик, 2020).

Висновки та перспективи подальших наукових розвідок. Запропоновані нами технології створення віртуальних та змішаних реальностей все частіше використовуються і спостерігаються бум розповсюдження гаджетів, пристроїв та мобільних додатків. Поряд із індустрією розваг, ці технології мають багато застосувань і в галузі освіти, як практичне імітаційне навчання здобувачів із запропонованої нами спеціальності. Таким чином, традиційні методи презентації та навчання витісняються або доповнюються з новими можливостями для вирішення професійних завдань, головним чином у сферах, де потрібні відмінні спеціальні або професійні навички. Загальним для всіх $\epsilon$ зусилля, використовуючи необхідні застосунки, яким повинні навчатися студенти, бути наближеними до більш безпосереднього досвіду, дій та сценаріїв, які мають бути підготовлені до ситуацій у реальному інформаційно-освітньому середовищі. Виникає необхідність подальших досліджень розробки та впровадження SM ART-комплексів у систему вищої освіти.

\section{ЛІТЕРАТУРА}

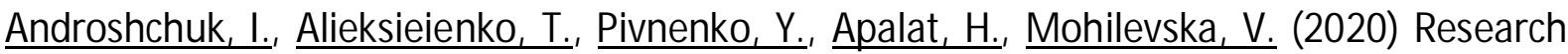
activity as a technology of activation of cognitive activity of students of higher education institutions. Systematic Reviews in Pharmacy, 11 (9), 474-477. https:// www.sysrevpharm.org/fulltext/196-1602485896.pdf?1606581764 Scopus

Ivliieva, O., Soroka, L., , Ilchenko, S., Shevchenko-Perepyolkina, R., Metil, T. (2019). Formation of a Strategic Model for Assessment of the Innovative Potential fan Enterprise. Academy of Strategic M anagement J ournal, Vol. 18, Issue 2.

Kavanagh, S., Luxton-Reilly, A., Wuensche, B., \& Plimmer, B. (2017). A systematic review of Virtual Reality in education. Themes in Science and Technology Education, 10 (2), 85-119.

Makarenko, L., \& Słabko, W. (2015). Informatization of education in the era of globalization of educational space. Artykuły i rozprawy, 20-29.

Makarenko, L., Slabko, V., Kononenko, A., Musorina, M., Smyrnova, I. (2020). Pedagogical aspects of ensuring the efficiency of education of Applicants of higher education 
institutions of Ukraine in the process of research of technical disciplines. Journal of Critical Reviews, 7 (13), 116-118. Scopus.

Андрощук, І. (2018). Проектування змісту професійної підготовки майбутніх учителів трудового навчання та технологій до організації позаурочної художньо-технічної діяльності учнівської молоді. Науковий вісник Інституту професійно-технічної освіти НАПН України. Професійна педагогіка, Вип. 16 (Androschuk, I. (2018). Designing the content of professional training of future teachers of labor education and technology for the organization of extracurricular artistic and technical activities of student youth. Scientific Bulletin of the Institute of Vocational Education of the National Academy of Pedagogical Sciences of Ukraine. Professional pedagogy, 16. DOI: 10.32835/2223-5752.2018.16.128-135.

Биков, В. Ю., Вернигора, С. М., Гуржій, А. М., Новохатько, Л. М., Спірін, О. М., \& Шишкіна, М. П. (2019). Проєктування і використання відкритого хмаро орієнтованого освітньо-наукового середовища закладу вищої освіти. Інформаційні технології і засоби навчання, 6 (74), 1-19 (Bykov, V. Yu., Vernihora, S. M., Hurzhii, A. M., Novokhatko, L. M., Spirin, O. M., \& Shyshkina, M. P. (2019). Design and use of open cloud-oriented educational and scientific environment of higher education institution. Information Technology and Teaching Aids, 6 (74), 1-19).

Буров, О., Быков, В., Литвинова, С. (2020). Эволюция ИКТ: от отдельных вычислительных задач к моделированию жизни. EasyChair, 4192. (Burov, O., Bykov, V., Litvinova, S. (2020). The evolution of ICT: from individual computational problems to life modeling. EasyChair, 4192).

Довгополик, К., Бражнікова, А. (2019). Педагогічна стратегія використання хмарних сервісів в активізації інтересу учнів старшої школи до вивчення іноземних мов. Науковий вісник Ізмаїльського державного гуманітарного університету, Вип. 45. Серія «Педагогічні науки», 44-52 (Dovhopolyk, K. Brazhnikova, A. (2019). Pedagogical strategy of using cloud services in activating the interest of high school students in learning foreign languages. Scientific Bulletin of Izmail State University for the Humanities. Issue 45. Series "Pedagogical Sciences", 44-52).

Довгополик, К. А. (2020). SM ART-комплекс як ефективний інструмент сучасного педагога. Матер. II наук.-практ. конф.:Теоретичні та практичні аспекти розвитку педагогічної освіти в Україні, м. Миколаїв, (сc. 95-98) (Dovhopolyk, K. A. (2020). SMART-complex as an effective tool of a modern teacher. Mater. II scientific-practical. conf.: Theoretical and practical aspects of the development of pedagogical education in Ukraine, M ykolayiv, (pp. 95-98)).

Емельянов, А. (2017). Учебный симулятор работы со станком чПУ в виртуальной реальности (Emelianov, A. (2017). Training simulator of working with a CNC machine

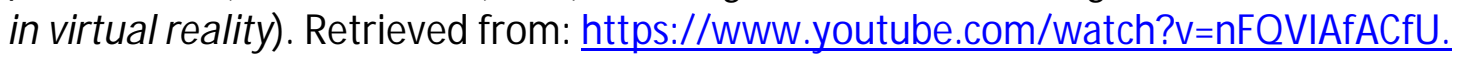

Макаренко, Л. Л., \& Остапчук, Т. С. (2019). Визначення сутності та змісту інформаційної компетентності майбутніх інженерів в процесі професійної підготовки. Науковий часопис Національного педагогічного університету імені М. П. Драгоманова. Серія 5: Педагогічні науки: реалії та перспективи, Buп. 72 (т. 2), 9-13 (Makarenko, L. L., \& Ostapchuk, T. S. (2019). Defining the essence and content of information competence of future engineers in the process of professional training. Scientific journal of the National Pedagogical University named after M.P. Drahomanov. Series 5: Pedagogical sciences: realities and prospects, Issue. 72 (Vol. 2), 9-13).

Мізюк, В., \& Абросімов, Є. (2019). Вибір електронної платформи для створення інформаційно-освітнього середовища закладу загальної середньої освіти. Науковий вісник Ізмаїльського державного гуманітарного університету. Серія 
«Педагогічні науки», Вип. 45, 90-100 (M iziuk, V., Abrosimov, Ye. (2019). Selection of an electronic platform for creating an information and educational environment for general secondary education. Scientific Bulletin of Izmail State University for the Humanities. Series "Pedagogical Sciences", Issue 45, 90-100. Retrieved from: http:// dspace.idgu.edu.ua/xmlui/handle/123456789/888.

Пригодій, М., Криворот, Т. (2020). Використання мережевих навчально-методичних комплексів у фаховій підготовці майбутніх викладачів. Профресійна педагогіка, 1 (20), 109-117 (Prihodii, M., Kryvorot, T. (2020). The use of network educational and methodological complexes in the professional training of future teachers. Professional pedagogy, 1 (20), 109-117. Retrieved from: https://doi.org/10.32835/2707-3092.2020.20.109-117.

Смирнова, І. М. (2018). Теоретичні і методичні основи професійної підготовки майбутніх учителів технологій до розроблення і використання електронних освітніх ресурсів (дис. на здобуття наук. ступеня д-ра пед. наук: 13.00 .04 «Теорія та методика професійної освіти» та 13.00.02 «Теорія та методика навчання (технічні дисципліни)») (Smirnova, I. М. (2018). Theoretical and methodological bases of professional training of future teachers of technologies for development and use of electronic educational resources (DSc thesis). Kyiv). Retrieved from: https://ivet.edu.ua/images/spets-rada/diss/Smyrnova_dis.pdf.

Яшанов, С., \& Дзус, С. (2019). Наукові засади застосування технологій комп'ютерного моделювання у фаховій підготовці учителів технологій. Освітній дискурс: збірник наукових праць, 10 (1-2), 45-58 (Yashanov, S., Dzus, S. (2019). Scientific principles of application of computer modeling technologies in professional training of technology teachers. Educational discourse: collection of scientific works, 10 (1-2), 45-58).

\section{PEЗЮME}

Допополик Екатерина, Певсе Андрея, Смирнова Ирина. Опыт Измаильского государственного гуманитарного университета в области внедрения образовательных инноваций.

Отражен опыт Измаильского государственного гуманитарного университета в области внедрения образовательных инноваций и особенности их применения с целью повышения мотивации соискателей высшего образования воспринимать знания и генерировать новые. Описанное внедрение образовательных инноваций в образовательный процесс соискателей высшего образования образовательно-профессиональной программы «Среднее: трудовое обучение и технологии. Информатика» первого уровня высшего образования на получение образовательного степени бакалавр за специальностью 014 Среднее образование, предметная специальность 014.10 Трудовое обучение и технологии, области знаний 01 Образование/Педагогика, квалификация: Бакалавр образования по трудовому обучению и технологиям. Учитель трудового обучения, технологий и информатики.

Ключевые слова: образовательные инновации, электронные образовательные ресурсы, информационное образовательная среда, цифровое поколение, облачные технологии, SMART-комплексы, виртуальная реальность, учитель трудового обучения и технологий.

\section{SUM M ARY}

Dopopolyk Kateryna, Pevse Andrea, Smyrnova Iryna. Experience of Ismail State University of Humanities in introducing educational innovations.

The problem of introducing educational innovations in educational establishments is analysed. The experience of Ismail State University of Humanities in introducing educational 
innovations and, especially, in applying them in order to increase the motivation of the applicants for higher education to absorb knowledge and generate new ones is reflected. Description of the introduction of educational innovations in the educational process of the applicants for higher education in the educational and vocational programme "Secondary education: vocational training and technology. Informatics", the first level of higher education for obtaining an educational baccalaureate degree in the specialty 014 Secondary education, subject specialty 014.10 Vocational education and technology, field of knowledge 01 Education/Pedagogy, Qualifications: Bachelor of Education in Vocational Training and Technology. Teacher of vocational education, technology and informatics by teachers of the Department of Mathematics, Informatics and Information Activities of the Ismail State University of Humanities. Pedagogical conditions for the implementation of experimental research and ways of their introduction in educational process of higher education institutions are proposed. Modern information technologies have been identified to improve the quality of the educational process through the introduction of innovative technologies.

Key words: educational innovations, electronic educational resources, information educational environment, digital generation, cloud technologies, SM ART-complexes, virtual reality, teacher of labour training and technologies.

\section{удк:005.336.4}

\section{Житомирська Тетяна \\ Дунайський інститут Національного університету «Одеська морська академія» ORCID ID 0000-0002-7015-0819}

Андрій Геннадійович

Інститут професійно-технічної освіти Національної академії педагогічних наук України ORCID ID 0000-0001-5153-422X

Олег Хищенко ДВНЗ «Переяслав-Хмельницький державний педагогічний університет імені Григорія Сковороди» ORCID ID 0000-0002-2653-9421

Тарас Остапчук Військова академія (м. Одеса) ORCID ID 0000-0001-7461-5508

DOI 10.24139/2312-5993/2020.09/156-166

\section{ІНТЕЛЕКТУАЛЬНИЙ КАПІТАЛ ЯК СКЛАДОВА ТЕХНІЧНОЇ КУЛЬТУРИ ФАХІВЦЯ}

у статті розкрито поняття інтелектуального капіталу компанії, інтелектуальної економіки, заснованої на знаннях, інтелектуальної «навчальної організації», «колективного знання». Опрацьовано й схарактеризовано інтелектуальну складову компанії, як необхідної технічної складової загальної вартості всієї фірми. Визначено основні сучасні інтелектуальні засоби спілкування. Висвітлено моделі інтелектуального розвитку та фактори успішного «інтелектуального управління навчанням». Охарактеризовано навички сучасних інтелектуалів-менеджерів та інтелектуальні підходи практичного управління знаннями на рівні компанії. Досліджено та схарактеризовано стратегію фрормування технічної культури майбутніх менеджерів. Наголошено на необхідності набуття 